\title{
Treatment of Intracranial Aneurysms with Hydrogel Coated Expandable Coils
}

\author{
Thorsteinn Gunnarsson, Paula Klurfan, Karel G. terBrugge, Robert A. Willinsky
}

\begin{abstract}
Background: Coiling of intracranial aneurysms with platinum coils sometimes results in relatively poor angiographic results which may be is related to low packing volumes achieved. Hydrogel coated expandable coils (HydroCoil@) have been shown to achieve better aneurysm volume filling which may potentially result in lower recanalization rates. Currently there is limited clinical data on their safety and efficacy in aneurysm treatment. Methods: We analyzed data from a prospectively collected database on patients treated at the Toronto Western Hospital. The analysis included the patients' characteristics, aneurysm size, packing, procedure related complications, recanalization and clinical outcome. Results: Twenty-nine aneurysms were treated with HydroCoils only or in combination with other coils. The average calculated filling of the aneurysm volume was $74-76 \%$. On the immediate post treatment angiograms, $44 \%$ of the berry type aneurysms were completely obliterated, $33 \%$ had a residual neck and, in $20 \%$, a residual aneurysm was seen. Follow-up imaging was available in 23 cases. On imaging follow-up (from 2 days to 11 months) one dissecting aneurysm had recanalized. There were six technical/medical complications with no clinical consequences. Two clinically significant procedural related complications occurred. Conclusions: HydroCoils can be used effectively to treat intracranial aneurysms. The volume expansion allows for much greater packing than described for bare platinum coils, which may result in better long-term results. The recanalization rate is low but the limited follow-up does not allow for any conclusion regarding the long-term outcome. The complication rate is similar to larger current series using bare platinum coils.
\end{abstract}

RÉSUMÉ: Traitement des anévrismes intracrâniens au moyen de microspires expansibles enduites d'hydrogel. Contexte : Le traitement des anévrismes intracrâniens avec des microspires de platine donne parfois des résultats angiographiques peu satisfaisants qui sont peut-être dus au faible remplissage obtenu. Les microspires expansibles enduites d'hydrogel (HydroCoil,) permettent un meilleur remplissage de la cavité de l'anévrisme, ce qui est susceptible de diminuer le taux de reperméabilisation. Il existe peu de données cliniques au sujet de leur sécurité et de leur efficacité dans le traitement des anévrismes. Méthodes : Nous avons analysé les données d'une base de données accumulées de façon prospective sur des patients traités au Toronto Western Hospital. Les caractéristiques des patients, la taille de l'anévrisme, l'entassement des microspires, les complications suite à l'intervention, la reperméabilisation et l'issue clinique ont été analysés. Résultats : Vingt-neuf anévrismes ont été traités au moyen d'HydroCoils seulement ou combinés à d'autres microspires. Le remplissage calculé moyen du volume anévrismal a été de 74 à $76 \%$. À l'angiographie effectuée immédiatement après le traitement, $44 \%$ des anévrismes ampullaires étaient complètement oblitérés, $33 \%$ avaient un collet résiduel et un anévrisme résiduel était visible chez $20 \%$ des patients. L'imagerie effectuée au cours du suivi, soit de 2 jours à 11 mois après l'intervention, était disponible chez 23 patients. Un anévrisme disséquant était reperméabilisé. Il y a eu 6 complications techniques ou médicales sans conséquences cliniques et deux complications reliées à l'intervention qui étaient significatives au point de vue clinique. Conclusions : Les HydroCoils peuvent être utilisés efficacement pour traiter les anévrismes intracrâniens. Leur expansion permet de les entasser beaucoup plus que les microspires de platine nus, ce qui est susceptible de donner de meilleurs résultats à long terme. Dans cette étude, le taux de reperméabilisation est faible. Cependant, le suivi est trop court et ne permet pas de tirer des conclusions sur l'issue à long terme. Le taux de complication était semblable à celui de plus grandes séries de cas traités au moyen de microspires de platine nues.

Can. J. Neurol. Sci. 2007; 34: 38-46

An international randomized clinical trial comparing endovascular and surgical treatment for ruptured intracranial aneurysms suitable to both treatment modalities has shown that endovascular treatment results in absolute risk reduction for death or dependency of $6.9 \%$ when compared with surgical clipping. ${ }^{1}$ To date, no randomized clinical trials have compared endovascular versus surgical clipping in unruptured aneurysms. Of concern is that the long-term results of endovascular treatment are currently unknown and aneurysms treated by coiling have the potential to recanalize and rupture. ${ }^{2}$ One of the factors considered to play a major role in the efficiency of coiling and aneurysm recurrence after coiling is the coil packing density, i.e. what volume of coils can fill the aneurysm volume. ${ }^{3}$ As a

From the Division of Neuroradiology (TG, PK, KGtB, RAW), Division of Neurosurgery (TG), Toronto Western Hospital, University of Toronto, Toronto, Ontario, Canada.

ReCEIVED APril 27, 2006. ACCEPTED IN FINAL FORM OCTOBER 28, 2006. Reprint requests to: Robert A. Willinsky, Division of Neuroradiology, Imaging Department, Toronto Western Hospital, 3MC-427, 399 Bathurst Street, Toronto, Ontario, M5T 2S8, Canada. 
result, new coils have been developed that take up more of the aneurysm volume in order to facilitate the healing process and improve the long-tem results. Recently hydrogel coated coils (HydroCoil@ Embolization System (HES), Microvention, Aliso Viejo, CA) were introduced to the market. ${ }^{4}$ As HydroCoils are exposed to the circulation they expand and take up more volume than corresponding platinum coils. If packing density is crucial in aneurysm treatment, expandable coils should have an advantage in endovascular treatment of intracranial aneurysms. The following report is based on a single center experience with the use of HydroCoils over a one year period in patients with ruptured and unruptured intracranial aneurysms.

\section{Patients, Patient Selection and Methods}

A database of the University of Toronto Brain Vascular Malformation Study Group on all endovascularly treated aneurysms has been prospectively collected since 1992. A total of 30 intracranial aneurysms in 29 patients have been selected for treatment with HydroCoils from July 2, 2004. Dr. Willinsky holds an institutional ethical approval for reviewing all patients who have had treatment with endovascular coiling for intracranial aneurysms at the Toronto Western Hospital. The patients did not sign an informed consent to be included in this study.

Initially, the patients selected for treatment with Hydrocoils had relatively large aneurysms or locations that are known to frequently recanalize such as at the basilar tip and in the paraopththalmic region. Choosing a larger aneurysm would also allow the use of larger microcatheters with more stability because HydroCoils are stiffer than regular coils. With more experience the aneurysm size was of less concern although we did not attempt to coil very small aneurysms or aneurysms where we felt that the microcatheter position would be unstable during the procedure.

The present analysis is updated as of August 8, 2005. The analysis included the clinical presentation, patients' characteristics, aneurysm location and size, results of treatment and procedure related complications and aneurysm recanalization. Patients who presented with SAH were evaluated using the World Federation of Neurological Surgeons Subarachnoid Hemorrhage Grading Scale (WFNS) and Fisher grading scale..$^{5,6}$ The clinical outcome was assessed at the last follow up visit or on discharge from hospital using the modified Rankin scale. ${ }^{1}$

All procedures were performed under general anesthesia using biplane angiography. After placement of a femoral sheath a diagnostic angiogram was performed with $3 \mathrm{D}$ reconstruction of the aneurysm. If the aneurysm was considered suitable for coiling the patients were fully heparinized keeping the activated clotting time between 250 and 300 seconds. When deployment of an intracranial stent was anticipated, the patients were preloaded with aspirin and clopidogrel. After placement of a guiding catheter different microcatheters were selected to deliver the coils into the aneurysm depending on the aneurysm characteristics. The procedures were performed under road map control. Generally, the approach was to use platinum coils for framing and then deploy as many HydroCoils as possible until the aneurysm was not filling on the following control injection.
When no more HydroCoils could be deployed for technical or safety reasons the coiling was completed with platinum coils. If the microcatheter was pushed out and it was felt that no more coils could be deployed safely or that it could not be repositioned the procedure was stopped. At the end of the procedure the heparinization was stopped but not reversed and the femoral sheath left in place and removed later.

HydroCoils need special preparation prior to deployment. To remove air from inside of the sheath containing the coil, Ringers Lactate was flushed through the detachment port. Then the coils were exposed to a warm Ringers Lactate solution. This softens the coil. HydroCoils are known to be stiffer than pure platinum coils. ${ }^{7}$ If needed, to soften the coils further prior to deployment, the coils were "steamed" over boiling water. As HydroCoils expand after exposure to the circulation there is limited time the operators have to deploy the coil until a decision has to be made if to retrieve or detach. This is usually about 4-5 minutes. Therefore, while pushing the coil into the microcatheter, a timer was set and the operators were updated every minute about the time passed. Finally the coils were detached using contrast solution injected through the detachment port using a $1 \mathrm{ml}$ syringe.

All coils used were documented. Aneurysm volume was calculated assuming that aneurysms were elliptical applying the formula: $4 \pi$ (height $/ 2 \mathrm{X}$ length/2 X width/2)/3. The coil volume $=\pi$ (radius $^{2} \mathrm{X}$ length, assuming that the HydroCoils were fully expanded. The packing density $=$ (coil volume/aneurysm volume) $\mathrm{X} 100 \% .^{8}$

All aneurysms were evaluated angiographically at the end of the procedure by biplane- and rotational angiography. Routinely all patients are currently followed with auto-triggered ellipticcentric-ordered three-dimensional gadolinium-enhanced MR angiography (ATECO MRA). ${ }^{9}$ In patients where there was concern of vasospasm development or in cases of claustrophobia, selective digital subtraction angiography (DSA) was performed. All DSA or ATECO MRA were evaluated by two of the authors (TG, PK) in a blinded fashion. In cases of disagreement a third interventional neuroradiologist was consulted to reach an agreement on the treatment results. The results of the coiling were classified as complete, residual neck or residual aneurysm. ${ }^{10}$

\section{RESULTS \\ Patient Characteristics}

Twenty-nine aneurysms were treated with HydroCoils in 28 patients, 17 female/11male, mean age of 52 (range 29-73). Tables 1-3 summarize the patients' characteristics including clinical and radiological outcomes. The patients were divided into three categories based on presentation and aneurysm characteristics. Eighteen aneurysms were treated in 17 patients presenting with SAH (Table 1) of which 10 were small $(<10 \mathrm{~mm})$ with no aneurysm less then $5.5 \mathrm{~mm}$ maximal diameter, 8 were large $(\geq 10 \mathrm{~mm})$. The mean longest diameter was $10.6 \mathrm{~mm}$. Seven patients with unruptured aneurysm or previously coiled recanalized aneurysms were treated (Table 2). Of those one was a giant basilar tip aneurysm. In addition four patients with "atypical" aneurysms were treated with HydroCoils, three dissecting aneurysms were treated with aneurysm coiling and 
Table 1: Characteristics, clinical and radiological outcome in patients who presented with aneurysmal SAH

\begin{tabular}{|c|c|c|c|c|c|c|c|c|c|c|c|}
\hline \multirow[b]{2}{*}{$\begin{array}{c}\text { Patient } \\
\text { no. }\end{array}$} & \multirow[b]{2}{*}{ Sex/age } & \multicolumn{2}{|c|}{ Presentation } & \multicolumn{5}{|c|}{ Aneurysm } & \multirow{2}{*}{$\begin{array}{c}\begin{array}{c}\text { Clinical } \\
\text { follow up }\end{array} \\
\mathrm{MRS}^{\mathrm{d}} / \text { last } \\
\text { follow up }\end{array}$} & \multicolumn{2}{|c|}{$\begin{array}{c}\text { Imaging follow } \\
\text { up }\end{array}$} \\
\hline & & WFNS $^{a}$ & $\begin{array}{l}\text { Fisher } \\
\text { grade }^{b}\end{array}$ & Location & $\begin{array}{l}\text { Longest } \\
\text { diameter } \\
(\mathrm{mm})\end{array}$ & $\begin{array}{c}\% \text { total } \\
\text { volume } \\
\text { packing }\end{array}$ & $\begin{array}{c}\text { \% volume } \\
\text { HydroCoil } \\
\text { of total } \\
\text { coil mass }\end{array}$ & $\begin{array}{l}\text { Immediate } \\
\text { angiographic } \\
\text { results }^{c}\end{array}$ & & $\begin{array}{c}\mathrm{f} / \mathrm{u} \\
\text { period }\end{array}$ & results \\
\hline 1 & $F / 37$ & 1 & 2 & $\begin{array}{l}\text { Right posterior } \\
\text { communicating }\end{array}$ & 9.5 & 20 & 55 & Neck filling & $0 / 6$ months & $\begin{array}{l}6 \\
\text { months }\end{array}$ & Stable \\
\hline 2 & $\mathrm{~F} / 59$ & 4 & 3 & Basilar tip & 8.1 & 137 & 95 & Complete & 1/1 week & no $f / u$ & \\
\hline 3 & $F / 46$ & 4 & 3 & $\begin{array}{l}\text { Anterior } \\
\text { communicating }\end{array}$ & 15.3 & 46 & 89 & Body filling & $1 / 11$ months & $\begin{array}{l}11 \\
\text { months }\end{array}$ & $\begin{array}{l}\text { Improved } \\
\text { complete }\end{array}$ \\
\hline 4 & $\mathrm{~F} / 67$ & 1 & 3 & Basilar tip & 6.2 & 62 & 78 & Complete & 0/1 week & no $f / u$ & \\
\hline 5 & $F / 66$ & 3 & 4 & $\begin{array}{l}\text { Left superior } \\
\text { cerebellar }\end{array}$ & 10.0 & 89 & 90 & Complete & $5 / 2$ months & 2 weeks & Stable \\
\hline 6 & $M / 61$ & 4 & 3 & $\begin{array}{l}\text { Left posterior } \\
\text { communicating }\end{array}$ & 6.0 & 74 & 86 & Complete & 0/1 month & 2 weeks & Stable \\
\hline 7 & $\mathrm{~F} / 73$ & 2 & 2 & Basilar tip & 15.0 & 57 & 77 & Body filling & $1 / 5$ months & $\begin{array}{l}6 \\
\text { months }\end{array}$ & Stable \\
\hline 8 & $F / 49$ & 1 & 3 & $\begin{array}{l}\text { Right carotid } \\
\text { termination }\end{array}$ & 9.0 & 100 & 86 & Body filling & 0/3 months & 1 month & $\begin{array}{l}\text { Improved } \\
\text {,neck } \\
\text { filling }\end{array}$ \\
\hline 9 & $F / 62$ & 2 & 4 & $\begin{array}{l}\text { Anterior } \\
\text { communicating }\end{array}$ & 16.0 & 71 & 97 & Neck filling & $0 / 2$ months & 2 weeks & Stable \\
\hline 10 & $F / 49$ & 3 & 4 & $\begin{array}{l}\text { Left } \\
\text { paraophthalmic }\end{array}$ & 14.2 & 105 & 96 & Complete & $3 / 3$ months & 1 week & Stable \\
\hline 11 & $M / 39$ & 4 & 4 & $\begin{array}{l}\text { Anterior } \\
\text { communicating }\end{array}$ & 16.6 & 83 & 93 & Complete & $4 / 3$ months & no $f / u$ & \\
\hline 12 & $F / 36$ & 1 & 3 & $\begin{array}{l}\text { Left carotid } \\
\text { termination }\end{array}$ & 10.0 & 64 & 81 & Complete & $1 / 2$ months & 1 week & Stable \\
\hline 13 & $\mathrm{M} / 43$ & 1 & 2 & $\begin{array}{l}\text { Anterior } \\
\text { communicating }\end{array}$ & 15.7 & 56 & 97 & Neck filling & $0 / 2$ months & no $f / u$ & \\
\hline 14 & $\mathrm{M} / 61$ & 1 & 2 & Basilar tip & 9.1 & 60 & 85 & Neck filling & 0/1 month & 1 week & Stable \\
\hline 15 & $\mathrm{M} / 54$ & 4 & 4 & Basilar Tip & 7.0 & 75 & 89 & Complete & $5 / 2$ weeks & 2 days & Stable \\
\hline 15 & $M / 54$ & 4 & 4 & $\begin{array}{l}\text { Left carotid } \\
\text { termination }\end{array}$ & 7.1 & 103 & 90 & Complete & $5 / 2$ weeks & 2 days & Stable \\
\hline 16 & $M / 61$ & 5 & 4 & Right vertebral & 5.5 & 103 & 70 & Neck filling & $5 /$ still in ICU & no $f / u$ & \\
\hline 17 & $F / 48$ & 5 & 4 & Basilar tip & 9.8 & 59 & 89 & Body filling & $5 /$ still in ICU & no $f / u$ & \\
\hline
\end{tabular}

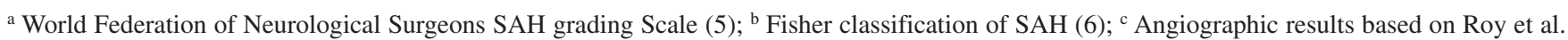
(10); ${ }^{\mathrm{d}}$ Modified Rankin Score (1)

parent vessel occlusion and in one case a pseudoaneurysm caused by a skull base tumor was coiled keeping the parent vessel open (Table 3).

\section{Results of Coiling}

All aneurysms were treated with HydroCoils alone or in a combination of HydroCoils and bare platinum coils. In one case (no. 1) Matrix ${ }^{\circledR}$ coils (Boston Scientific, Natick, MA) were also used in combination with HydroCoils and bare platinum coils. In two cases where the aneurysm configuration was unfavorable, a Neuroform ${ }^{\circledR}$ stent (Boston Scientific) was used to facilitate the coiling. One patient had previously been treated by stent assisted coiling. In three cases balloon remodeling techniques were used. No complications were associated with the use of stents or balloon remodeling. In the 25 berry type aneurysms that were treated with coiling 11 (44\%) were completely obliterated, 9 (36\%) had a residual neck and 5 (20\%) had residual aneurysm filling. Calculated mean aneurysm packing was $76 \%$ (range, 20$137 \%$ ) in patients with SAH from berry aneurysms and in patients with unrurptured or recanalized aneurysms the mean packing was $74 \%$ (range, 62-94\%) (Table 1, Table 2).

\section{Peri-procedural Complications}

Seven complications with no clinical consequences occurred in five procedures (17\%). In three cases a small thrombus formed at the neck of the aneurysm during the coiling procedure. These were treated immediately with a single bolus of abciximab resulting in complete disappearance of the clot by the end of the procedure. In two cases premature coil detachment occurred. In the first case the coil was retrieved with a snare. In the second case, the coil detached halfway within the microcatheter during an attempt to retrieve the coil after unsatisfactory positioning. This occurred after four minutes of coil exposure to the bloodstream. The coil was successfully retrieved by removing the microcatheter. Two patients developed a small retroperitoneal hematoma after removal of the groin sheath. One had been treated with aspirin and clopidogrel and the other had received abciximab during the coiling procedure.

There was no mortality in this series but two patients $(7 \%)$ suffered from complications that could be related to the coiling procedure. One patient, with a ruptured wide neck $10.8 \mathrm{~mm}$ left superior cerebellar aneurysm, developed multiple infarcts in the posterior circulation (outcome, MRS 5) some of which were outside of the territory of the parent vessel treated. In a patient 
Table 2: Characteristics, clinical and radiological outcome in patients with unruptured or recanalized aneurysms on follow up treated with HydroCoils

\begin{tabular}{|c|c|c|c|c|c|c|c|c|c|c|}
\hline \multirow[b]{2}{*}{$\begin{array}{c}\text { Patient } \\
\text { no. }\end{array}$} & \multirow[b]{2}{*}{ Sex/age } & Presentation & \multicolumn{5}{|c|}{ Aneurysm } & $\begin{array}{l}\text { Clinical } \\
\text { follow } \\
\text { up }\end{array}$ & \multicolumn{2}{|c|}{ Imaging follow up } \\
\hline & & Presentation & Location & $\begin{array}{l}\text { Size } \\
(\mathrm{mm})\end{array}$ & $\begin{array}{l}\% \text { total } \\
\text { packing }\end{array}$ & $\begin{array}{l}\text { \% volume } \\
\text { HydroCoil o1 } \\
\text { total coil } \\
\text { mass }\end{array}$ & $\begin{array}{l}\text { Immediate } \\
\text { angiographic } \\
\text { results }^{\mathrm{a}}\end{array}$ & $\begin{array}{l}M^{M R S} / \text { last } \\
\text { follow up }\end{array}$ & $\begin{array}{c}\mathrm{f} / \mathrm{u} \\
\text { period }\end{array}$ & results \\
\hline 18 & $F / 47$ & $\begin{array}{l}\text { Asymptomatic, positive } \\
\text { family history, found on } \\
\text { screening }\end{array}$ & $\begin{array}{l}\text { Left } \\
\text { paraophthalmic }\end{array}$ & 14.0 & 64 & 94 & Neck filling & 0/5 months & $\begin{array}{l}4 \\
\text { months }\end{array}$ & $\begin{array}{l}\text { Improvement, } \\
\text { remnant } \\
\text { smaller }\end{array}$ \\
\hline 19 & $M / 55$ & $\begin{array}{l}\text { Asymptomatic, positive } \\
\text { family history, found on } \\
\text { screening }\end{array}$ & Basilar Tip & 5.7 & 94 & 91 & Complete & 0/6 months & $\begin{array}{l}6 \\
\text { months }\end{array}$ & Stable \\
\hline 20 & $M / 53$ & $\begin{array}{l}\text { Asymptomatic, } \\
\text { incidental }\end{array}$ & Basilar trunk & 8.7 & 64 & 90 & Neck filling & 0/8 months & $\begin{array}{l}6 \\
\text { months }\end{array}$ & Stable \\
\hline 21 & $F / 58$ & $\begin{array}{l}\text { Prior SAH. } \\
\text { Recanalization on follow } \\
\text { up, previously coiled } \\
\text { with bare platinum coils } \\
\text { in } 2002\end{array}$ & $\begin{array}{l}\text { Anterior } \\
\text { communicating }\end{array}$ & 10.0 & 75 & 91 & Neck filling & $\begin{array}{l}\text { 2/10 } \\
\text { months }\end{array}$ & $\begin{array}{l}12 \\
\text { months }\end{array}$ & Stable \\
\hline 22 & $F / 44$ & Asymptomatic,incidental & $\begin{array}{l}\text { Right } \\
\text { paraophthalmic }\end{array}$ & 8.0 & 83 & 89 & Complete & $\begin{array}{l}\text { 0/10 } \\
\text { months }\end{array}$ & $\begin{array}{l}11 \\
\text { months }\end{array}$ & Stable \\
\hline 23 & $\mathrm{~F} / 67$ & $\begin{array}{l}\text { Memory loss from } \\
\text { bilateral thalamic } \\
\text { edema }\end{array}$ & Basilar tip & 21.0 & 62 & 89 & Body filling & 0/3 months & $\begin{array}{l}2 \\
\text { months }\end{array}$ & Stable \\
\hline 24 & $\mathrm{M} / 45$ & $\begin{array}{l}\text { Prior SAH. } \\
\text { Recanalization on follow } \\
\text { up, intentionally } \\
\text { incomplete initial } \\
\text { treatment with bare } \\
\text { platinum and Matrix } \\
\text { coils }\end{array}$ & Basilar tip & 7.9 & 75 & 89 & Neck filling & 0/1 week & & \\
\hline
\end{tabular}

${ }^{\mathrm{a} A n g i o g r a p h i c ~ r e s u l t s ~ b a s e d ~ o n ~ R o y ~ e t ~ a l . ~(10) ; ~}{ }^{\mathrm{b}}$ Modified Rankin Score (1)

Table 3: Characteristics, clinical and radiological outcomes in patients with atypical aneurysms caused by dissection or tumor invasion

\begin{tabular}{|c|c|c|c|c|c|c|c|c|c|}
\hline \multirow[b]{2}{*}{$\begin{array}{c}\text { Patient } \\
\text { no. }\end{array}$} & \multirow[b]{2}{*}{ Sex/age } & \multirow{2}{*}{$\begin{array}{l}\text { Presentation } \\
\text { Presentation }\end{array}$} & \multicolumn{4}{|c|}{ Aneurysm } & \multirow{2}{*}{$\begin{array}{c}\text { Clinical follow } \\
\text { up } \\
\text { MRS/last follow } \\
\text { up }\end{array}$} & \multicolumn{2}{|c|}{$\begin{array}{c}\text { Imaging follow } \\
\text { up }\end{array}$} \\
\hline & & & Location & $\begin{array}{l}\text { Size } \\
(\mathrm{mm})\end{array}$ & Treatment & $\begin{array}{l}\text { Immediate } \\
\text { angiographic } \\
\text { results }\end{array}$ & & $\begin{array}{c}\mathrm{f} / \mathrm{u} \\
\text { period }\end{array}$ & results \\
\hline 25 & $\mathrm{~F} / 58$ & $\begin{array}{l}\text { Patient with a large } \\
\text { skull base tumor and } \\
\text { transient ischemic } \\
\text { attacks }\end{array}$ & $\begin{array}{l}\text { Left cavernous } \\
\text { pseudoaneurysm in } \\
\text { an area of tumor } \\
\text { invasion }\end{array}$ & 12.0 & Aneurysm coiling & Body filling & $\begin{array}{l}2 \text { (related to tumor } \\
\text { progression)/2 } \\
\text { months }\end{array}$ & 2 months & $\begin{array}{l}\text { MRI } \\
\text { shows no } \\
\text { residual }\end{array}$ \\
\hline 26 & $\mathrm{M} / 29$ & $\begin{array}{l}\text { Ischemic stroke } \\
\text { (thalamic) }\end{array}$ & $\begin{array}{l}\text { Right P2 dissecting } \\
\text { aneurysm }\end{array}$ & 26.0 & $\begin{array}{l}\text { Aneurysm coiling } \\
\text { and parent vessel } \\
\text { occlusion }\end{array}$ & Complete & $\begin{array}{l}1 \text { (numbness left } \\
\text { side since } \\
\text { presentation)/5 } \\
\text { months }\end{array}$ & 6 months & $\begin{array}{l}8 \times 8 \mathrm{~mm} \\
\text { recurrence }\end{array}$ \\
\hline 27 & $F / 36$ & $\mathrm{SAH}$ & $\begin{array}{l}\text { Right P3 dissecting } \\
\text { aneurysm }\end{array}$ & 9.0 & $\begin{array}{l}\text { Aneurysm coiling } \\
\text { and parent vessel } \\
\text { occlusion }\end{array}$ & Complete & $1 / 2$ months & 2 months & Complete \\
\hline 28 & $\mathrm{M} / 63$ & $\begin{array}{l}\text { Headache and left } \\
\text { seventh nerve cranial } \\
\text { palsy }\end{array}$ & Left vertebral artery & 11.4 & $\begin{array}{l}\text { Aneurysm coiling } \\
\text { and parent vessel } \\
\text { occlusion }\end{array}$ & Body filling & $1 / 1$ week & 1 month & Complete \\
\hline
\end{tabular}

with a $15.9 \mathrm{~mm}$ ruptured basilar tip aneurysm, a coil loop herniated into the posterior cerebral artery causing infarction in the corresponding vascular territory resulting in a visual field defect (MRS 1 on last follow-up).

\section{Clinical Outcome}

Of the 29 patients, 24 had good clinical outcome (modified
Rankin scale score of 0-2). All patients with unruptured or atypical aneurysms either improved or remained unchanged neurologically after the treatment. Five patients suffered a poor neurological outcome (modified Rankin scale score of 3-6) on last follow-up or on discharge from hospital. All had presented with SAH in poor clinical grade, WFNS of 3-5. 


\section{Aneurysm Recanalization}

In one patient with a giant $\mathrm{P} 2$ dissecting aneurysm, treated with coiling and parent vessel occlusion, with complete immediate results, recurrence of the aneurysm was seen on a six month follow up ATECO-MRA. No other recurrences were observed. In three cases an improvement was observed with no or less filling of the aneurysm (Figure 1).

\section{DISCUSSION}

This is one of the first single-center clinical series describing the use of hydrogel covered expandable coils for the treatment of various types of intracranial aneurysms. Overall, the results are promising, but a much longer clinical and angiographic followup is needed to make any firm conclusions about the long-term efficacy of HydroCoils in intracranial aneurysm treatment.

Gugliemi detachable coils have been in use for more than a decade. ${ }^{11,12}$ These are bare platinum coils. The main concern with the use of these coils is the relatively high rate of incomplete occlusion and high recanalization rates. Raymond et $\mathrm{al}^{13}$ reviewed their first ten year experience with GDC in 501 ruptured and unruptured aneurysms treated in 466 patients. In only $35.9 \%$ of the cases were they able to achieve complete occlusion of the aneurysm and on follow-up, at a mean of 12.31 months $33.6 \%$ of the aneurysms showed evidence of recurrence. These results are in keeping with results from other large series showing immediate complete occlusion in $30-65.8 \%$ of the cases $^{14-18}$ with recanalization of $20.9-30 \%{ }^{16-18}$ on short-term or middle-term follow-up angiograms.

Clinical and anatomical factors that have been found to be associated with recanalization are aneurysms that present with $\mathrm{SAH}$, size, location in the posterior fossa or terminus type, width of the aneurysm neck, suboptimal initial angiographic results and

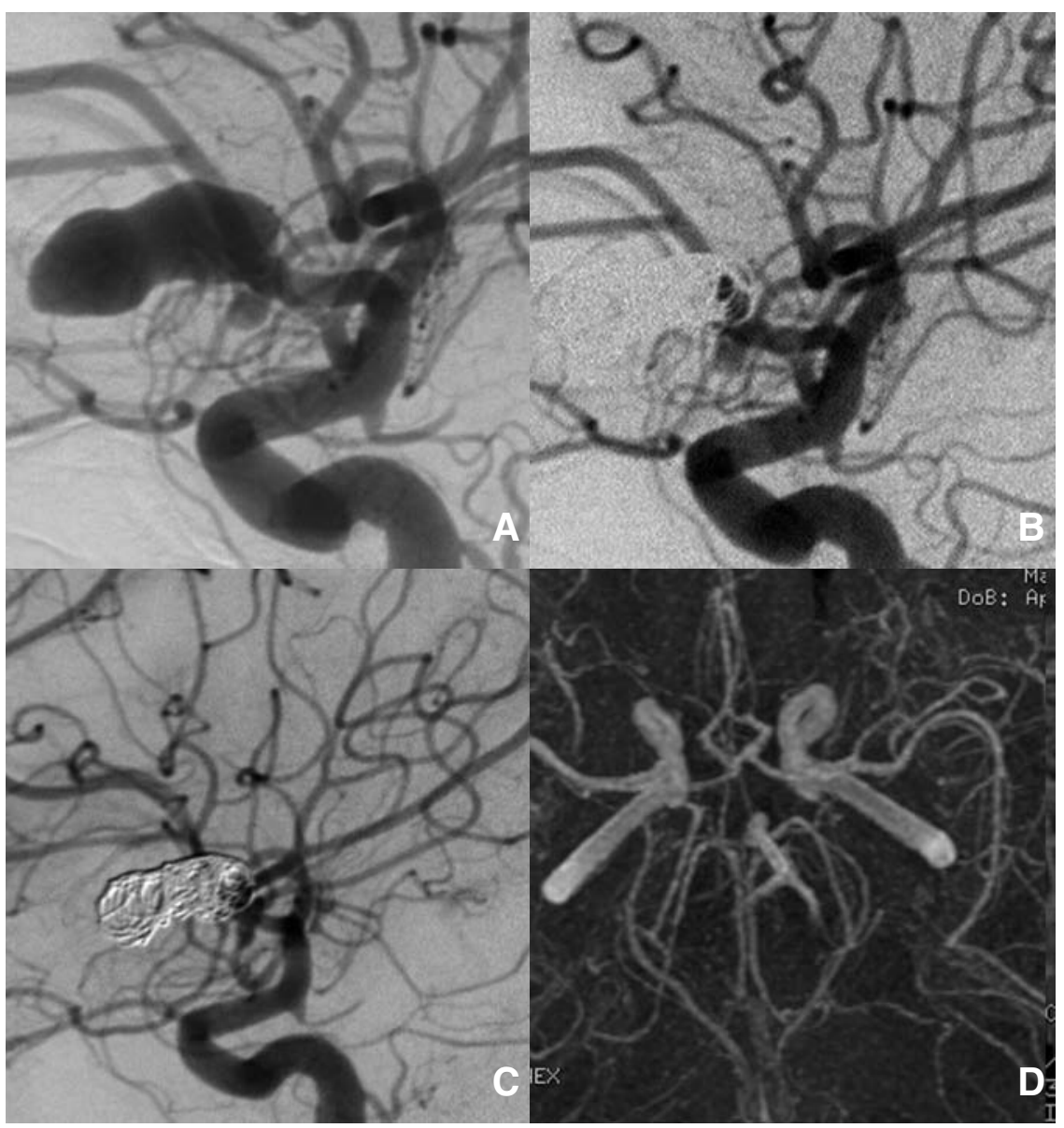

Figure 1: a. This 46-year-old female presented with SAH from a bi-lobule shaped anterior communicating aneurysm. She was treated with three HydroCoils and two platinum coils. $b$. On immediate post-treatment angiogram residual filling of the aneurysm and the small inferior lobule is seen. c. Control angiogram 7 days later shows less filling. $d$. On 11 month follow-up ATECO-MRI no residual is seen. 


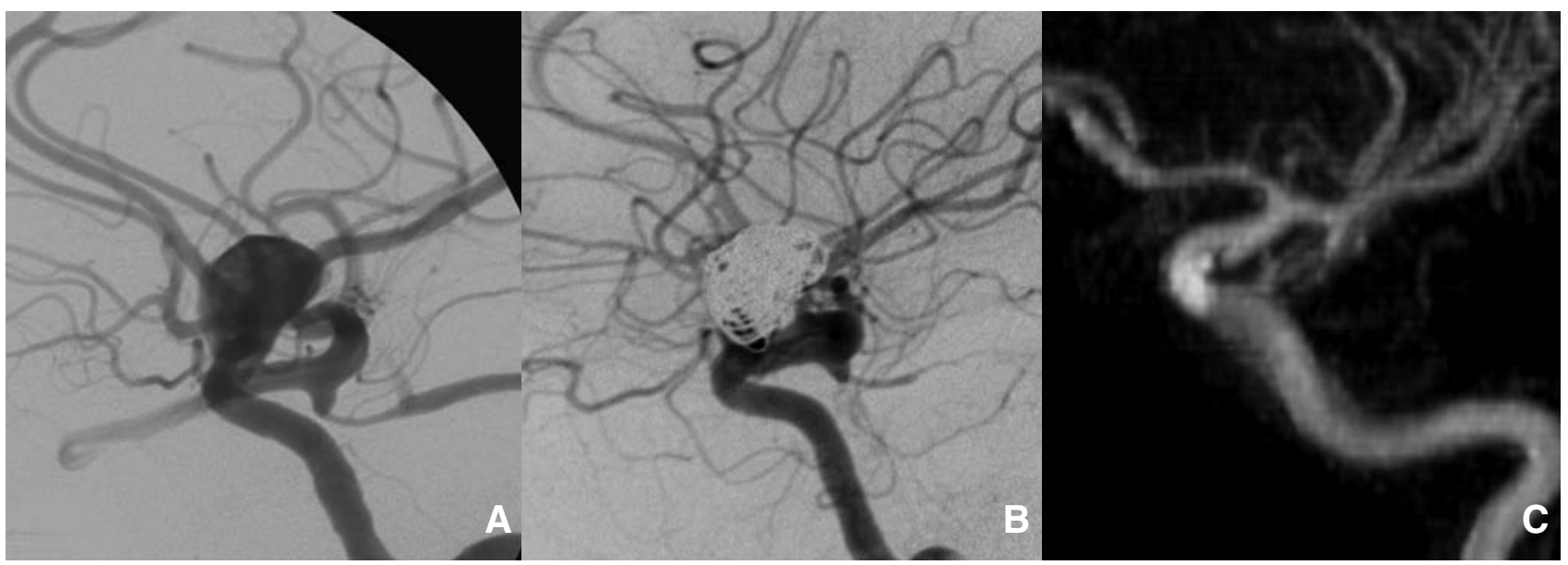

Figure 2: a. This 47-year-old female with an unruptured paraophthalmic aneurysm was treated with 9 HydroCoils and 1 platinum coil. b. On immediate post-treatment angiogram residual filling is seen. $c$. On the four month follow-up ATECO-MRI no evidence of aneurysm filling is seen.

length of follow up. ${ }^{13,16-20}$ Clinical and experimental evidence suggests that packing density plays a large role in the immediate and long term results of coiling. Sluzewski et $\mathrm{al}^{3}$ studied the association between aneurysm packing and coil compaction in 145 aneurysms treated with platinum coils with a recanalization rate of $28 \%$. Low packing volume was obtained in aneurysms larger than $600 \mathrm{~mm}^{3}$ with average packing of only $16.7 \%$. A strong relationship was found between packing density and coil compaction, with no recurrences in aneurysms less than 600 $\mathrm{mm}^{3}$ if the packing volume was $24 \%$ or more. In a similar study by Kai and coworkers in 62 patients with ruptured intracranial aneurysms treated with GDC, $25.8 \%$ showed evidence of coil compaction on follow-up. ${ }^{19}$ Their main conclusion was that the probability of coil compaction was significantly higher when coil packing ratio was less than $50 \%$. These results, along with other clinical and experimental evidence, strongly suggest that packing has a major impact on stability of coiled aneurysms. ${ }^{21-24}$

Techniques that allow for better packing of aneurysms such as balloon assisted coiling, the use of stents for the treatment of wide neck aneurysms and thicker-, softer- or more complex shaped coils have been described. ${ }^{25-29}$ HydroCoils are made of platinum helical coils coated with a layer of hydrophilic, acrylic polymer (hydrogel) which in contact with blood, by diffusion through the polymer, causes disentanglement of polymer chains and swelling. ${ }^{30}$ An experimental study in rabbits has shown that treatment with HydroCoils allows for more dense packing of aneurysms than seen in aneurysms treated with platinum coils and histopathological analysis shows minimal inflammatory reaction with thin layer of fibrous tissue traversing the neck of the aneurysm. ${ }^{4}$ In a recent study in the same model comparing HydroCoils, GDC and Matrix coils, greatest packing and angiographic durability was achieved with HydroCoils. ${ }^{31}$ In an experimental model in dogs, greater packing, less coil compaction and thicker neointima layer at the aneurysm neck was observed in aneurysms treated with HydroCoils compared with GDC. ${ }^{32}$

Published clinical data on the safety and efficacy of the use of HydroCoils is limited. ${ }^{7,8,33-37}$ Cloft and coworkers compared the packing of similar sized aneurysms using HydroCoils and platinum coils. ${ }^{8}$ A significantly greater packing was achieved with HydroCoils compared with platinum coils ( $72 \%$ vs. $32 \%$ ). Arthur et al recently published preliminary results on 33 aneurysms in 30 patients treated with HydroCoils alone or in a combination with other coils. ${ }^{7}$ Complete or near complete occlusion was achieved in $79 \%$ of the aneurysms on the immediate post treatment angiogram. In two patients attempted HydroCoil placement was unsuccessful. No permanent morbidity or mortality occurred as a result of the use of HydroCoils. Short term follow up angiograms (three-six months) were available for 23 of the aneurysms treated, with four aneurysms showing recurrence or coil compaction. One of those patients had been treated with intentional subtotal occlusion. ${ }^{7}$ Deshaies and coworkers treated 12 aneurysms with HydroCoils. ${ }^{35}$ The mean filling volume was $52 \%$. On six-month follow up all aneurysms were stable except for one that had improved and one giant ophthalmic aneurysm that had recanalized. Our results confirm the results from others demonstrating a high packing density of around 75\% with the use of HydroCoils and stable or, interestingly, improved appearance on limited short term follow-up (Figures 1-2). Whether the use of hydrocoils can thus allow for accepting suboptimal angiographic results at the end of the procedure can not be supported with the current available literature. The aneurysms in this series are relatively large and many are in locations that are known to recanalize, such as paraophthalmic, carotid termination and basilar tip (Figure 2). ${ }^{16,19,20}$ Therefore, we feel that the results are encouraging but the limited follow-up does not allow for any conclusion regarding the long-term follow-up. One giant dissecting P2 aneurysm has recanalized on follow-up. This is 


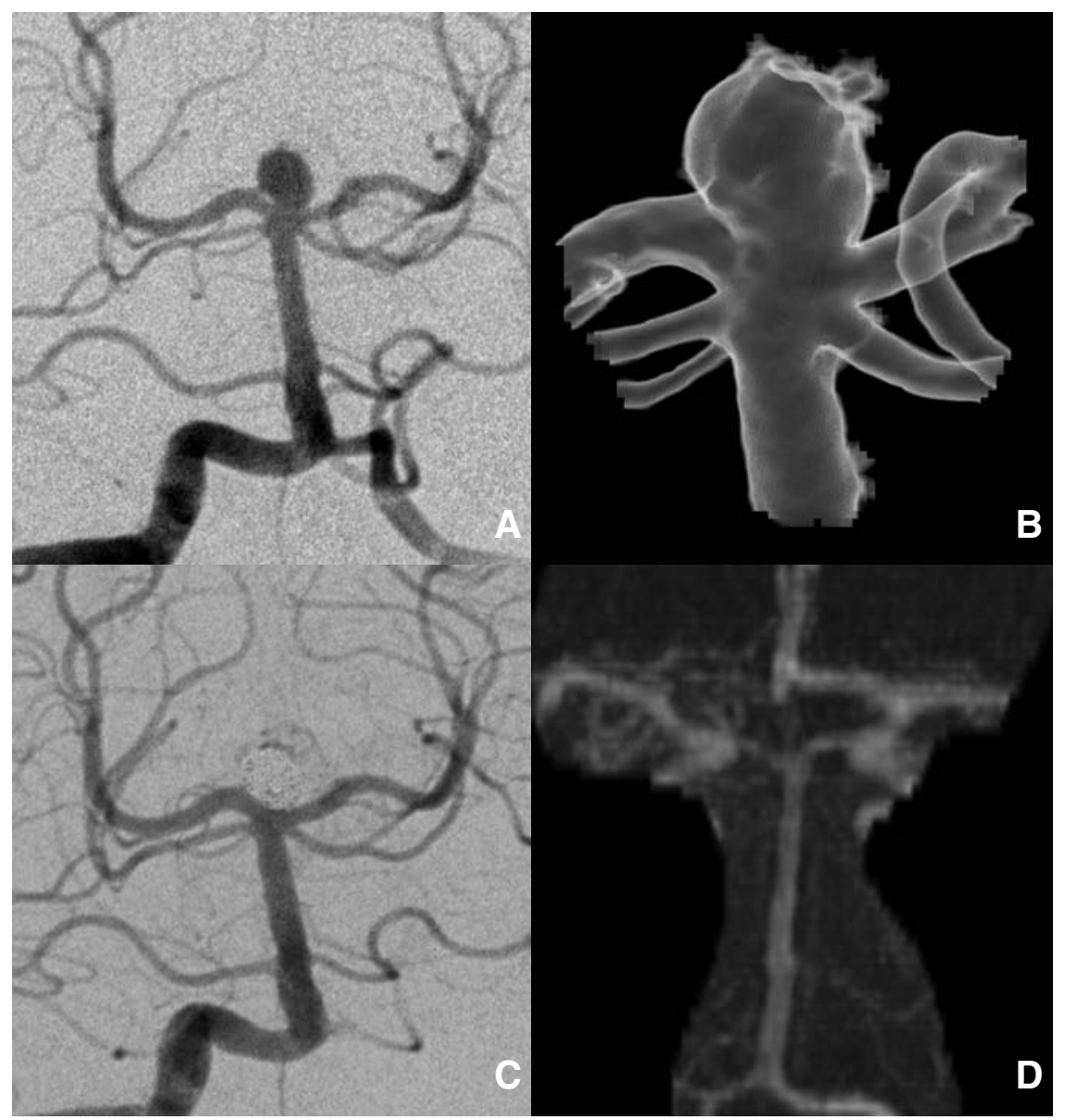

Figure 3: a. This 55-year-old male with an unruptured basilar tip aneurysm was treated with three HydroCoils and one platinum coil. $b$. Three dimensional reconstruction of the aneurysm. $c$. Immediate post-treatment angiogram shows complete obliteration of the aneurysm. $d$. On the 6 month follow-up ATECO-MRI no aneurysm filling is seen.

most likely a result of incomplete proximal occlusion of the weak parent vessel segment with further dissection of the vessel. HydroCoils have been used to for parent vessel occlusion by others with good results. ${ }^{33}$

The $7 \%$ rate of complications with permanent neurological morbidity is comparable to other large series using platinum coils for the treatment of ruptured and unruptured aneurysms, with complication rates ranging from 4-9.3\%. ${ }^{14,16,17,38-40}$ One patient developed a visual field deficit after a coil loop herniated into the posterior cerebral artery. This is a previously described complication in cases of basilar tip aneurysms treated with GDC..$^{41}$ In three cases $(10 \%)$ a small thrombus was observed at the neck of the aneurysm during the procedure which was treated with abciximab resulting in complete resolution. This is also a known complication during aneurysm coiling using platinum coils, occurring in $2.5-11 \%$ of cases. ${ }^{42}$

A recent case report described two cases of aseptic meningitis after endovascular treatment of intracranial aneurysms with a mixture of Matrix and HydroCoils. ${ }^{43}$ In our series none of the patients had this complication and in only one case were these coils used in combination. We have chosen to use new generation coils only in combination with platinum coils in order to make analysis of the efficacy and safety of different technologies easier.

The limited time allowed for placing HydroCoils before detachment or retrieval does not allow for repeated attempts for correct placement. With more experience with their use we did not find this especially challenging as, in most cases, placement of HydroCoils was not attempted if the microcatheter position was found to be unstable or if the coils were considered likely to herniate into the parent vessel. In such cases, soft platinum coils were used. Although no direct comparison was made with our previous cases using bare platinum coils only, it is our impression that fewer coils are needed to achieve complete packing of aneurysms using HydroCoils (Figure 3). HydroCoils are stiff compared with platinum coils but, with hydration in a 
warm Ringers Lactate solution and with steaming this was not found to cause any special problems and no intraprocedural rupture occurred during the procedures. ${ }^{7}$ In two cases a premature coil detachment occurred. In one case it was a "true" premature detachment but in the second case, the time allowed for manipulating the coil had most likely passed and on attempted retrieval the coil got stuck in the microcather and, upon pulling, it detached. Both were retrieved successfully without complications.

The balloon remodeling technique or stents were used in only a few cases. No complications were associated with these techniques which have been previously described with the use of HydroCoils. $^{7,34}$

In order to avoid the risks of conventional DSA, our current policy is to follow up all coiled aneurysms with ATECO MRA and only in cases of uncertainty to proceed with DSA. ${ }^{13,44}$ This is based on experience from our institution demonstrating excellent correlation between DSA and ATECO MRA. ${ }^{9}$ The study showed that ATECO MRA had sensitivity of $81 \%$ and specificity of $88 \%$ and was superior to time of flight in demonstrating residual filling of coiled intracranial aneurysm. Therefore, centers that use MRA for the follow-up of coiled intracranial aneurysms need to develop and evaluate high quality gadolinium MRA or other non-invasive techniques before substituting DSA.

HydroCoils can be deployed and used to treat ruptured and unruptured intracranial aneurysms in humans. The complication rate is similar to current series using conventional platinum coils.

\section{Disclosure}

The authors have no financial interest in the product described in this paper and are not shareholders in Microvention. Microvention did not provide funding for this study.

\section{REFERENCES}

1. Molyneux A, Kerr R, Stratton I, Sandercock P, Clarke M, Shrimpton J, et al. International Subarachnoid Aneurysm Trial (ISAT) of neurosurgical clipping versus endovascular coiling in 2143 patients with ruptured intracranial aneurysms: a randomised trial. Lancet. 2002;360(9342):1267-74.

2. Derdeyn CP, Barr JD, Berenstein A, Connors JJ, Dion JE, Duckwiler GR, et al. The International Subarachnoid Aneurysm Trial (ISAT): a position statement from the Executive Committee of the American Society of Interventional and Therapeutic Neuroradiology and the American Society of Neuroradiology. AJNR Am J Neuroradiol. 2003;24(7):1404-8.

3. Sluzewski M, van Rooij WJ, Slob MJ, Bescos JO, Slump CH, Wijnalda D. Relation between aneurysm volume, packing, and compaction in 145 cerebral aneurysms treated with coils. Radiology. 2004;231(3):653-8.

4. Kallmes DF, Fujiwara NH. New expandable hydrogel-platinum coil hybrid device for aneurysm embolization. AJNR Am J Neuroradiol. 2002;23(9):1580-8.

5. Report of World Federation of Neurological Surgeons Committee on a Universal Subarachnoid Hemorrhage Grading Scale. J Neurosurg. 1988;68(6):985-6.

6. Kistler JP, Crowell RM, Davis KR, Heros R, Ojemann RG, Zervas $\mathrm{T}$, et al. The relation of cerebral vasospasm to the extent and location of subarachnoid blood visualized by CT scan: a prospective study. Neurology. 1983;33(4):424-36.

7. Arthur AS, Wilson SA, Dixit S, Barr JD. Hydrogel-coated coils for the treatment of cerebral aneurysms: preliminary results. Neurosurg Focus. 2005;18(2):E1.
8. Cloft HJ, Kallmes DF. Aneurysm packing with HydroCoil Embolic System versus platinum coils: initial clinical experience. AJNR Am J Neuroradiol. 2004;25(1):60-2.

9. Farb RI, Nag S, Scott JN, Willinsky RA, Marotta TR, Montanera WJ, et al. Surveillance of intracranial aneurysms treated with detachable coils: a comparison of MRA techniques. Neuroradiology. 2005;47(7):507-15.

10. Roy D, Milot G, Raymond J. Endovascular treatment of unruptured aneurysms. Stroke. 2001;32(9):1998-2004.

11. Guglielmi G, Vinuela F, Dion J, Duckwiler G. Electrothrombosis of saccular aneurysms via endovascular approach. Part 2: preliminary clinical experience. J Neurosurg. 1991;75(1):8-14.

12. Guglielmi G, Vinuela F, Sepetka I, Macellari V. Electrothrombosis of saccular aneurysms via endovascular approach. Part 1: electrochemical basis, technique, and experimental results. J Neurosurg. 1991;75(1):1-7.

13. Raymond J, Guilbert F, Weill A, Georganos SA, Juravsky L, Lambert A, et al. Long-term angiographic recurrences after selective endovascular treatment of aneurysms with detachable coils. Stroke. 2003;34(6):1398-403.

14. Henkes H, Fischer S, Weber W, Miloslavski E, Felber S, Brew S, et al. Endovascular coil occlusion of 1811 intracranial aneurysms: early angiographic and clinical results. Neurosurgery. 2004;54(2):268-80; discussion 80-5.

15. Koivisto T, Vanninen R, Hurskainen H, Saari T, Hernesniemi J, Vapalahti M. Outcomes of early endovascular versus surgical treatment of ruptured cerebral aneurysms. A prospective randomized study. Stroke. 2000;31(10):2369-77.

16. Sluzewski M, van Rooij WJ, Rinkel GJ, Wijnalda D. Endovascular treatment of ruptured intracranial aneurysms with detachable coils: long-term clinical and serial angiographic results. Radiology. 2003;227(3):720-4.

17. Ng P, Khangure MS, Phatouros CC, Bynevelt M, ApSimon H, McAuliffe W. Endovascular treatment of intracranial aneurysms with Guglielmi detachable coils: analysis of midterm angiographic and clinical outcomes. Stroke. 2002;33(1):210-7.

18. Murayama Y, Nien YL, Duckwiler G, Gobin YP, Jahan R, Frazee J, et al. Guglielmi detachable coil embolization of cerebral aneurysms: 11 years' experience. J Neurosurg. 2003;98(5):959-66.

19. Kai Y, Hamada J, Morioka M, Yano S, Kuratsu J. Evaluation of the stability of small ruptured aneurysms with a small neck after embolization with Guglielmi detachable coils: correlation between coil packing ratio and coil compaction. Neurosurgery. 2005;56(4):785-92; discussion -92.

20. Vallee JN, Aymard A, Vicaut E, Reis M, Merland JJ. Endovascular treatment of basilar tip aneurysms with Guglielmi detachable coils: predictors of immediate and long-term results with multivariate analysis 6-year experience. Radiology. 2003; 226(3):867-79.

21. Reul J, Weis J, Spetzger U, Konert T, Fricke C, Thron A. Long-term angiographic and histopathologic findings in experimental aneurysms of the carotid bifurcation embolized with platinum and tungsten coils. AJNR Am J Neuroradiol. 1997;18(1):35-42.

22. Kawanabe Y, Sadato A, Taki W, Hashimoto N. Endovascular occlusion of intracranial aneurysms with Guglielmi detachable coils: correlation between coil packing density and coil compaction. Acta Neurochir (Wien). 2001;143(5):451-5.

23. Groden C, Laudan J, Gatchell S, Zeumer H. Three-dimensional pulsatile flow simulation before and after endovascular coil embolization of a terminal cerebral aneurysm. J Cereb Blood Flow Metab. 2001;21(12):1464-71.

24. Reul J, Spetzger U, Weis J, Sure U, Gilsbach JM, Thron A. Endovascular occlusion of experimental aneurysms with detachable coils: influence of packing density and perioperative anticoagulation. Neurosurgery. 1997;41(5):1160-5; discussion 5-8.

25. Slob MJ, van Rooij WJ, Sluzewski M. Coil thickness and packing of cerebral aneurysms: a comparative study of two types of coils. AJNR Am J Neuroradiol. 2005;26(4):901-3. 
26. Moret J, Cognard C, Weill A, Castaings L, Rey A. The 'remodelling technique' in the treatment of wide neck intracranial aneurysms: angiographic results and clinical follow-up in 56 cases. Interventional Neuroradiology. 1997;3(1):21-35.

27. dos Santos Souza MP, Agid R, Willinsky RA, Cusimano M, Montanera W, Wallace MC, et al. Microstent-assisted coiling for wide-necked intracranial aneurysms. Can J Neurol Sci. 2005;32(1):71-81.

28. Piotin M, Iijima A, Wada H, Moret J. Increasing the packing of small aneurysms with complex-shaped coils: an in vitro study. AJNR Am J Neuroradiol. 2003;24(7):1446-8.

29. Piotin M, Liebig T, Feste CD, Spelle L, Mounayer C, Moret J. Increasing the packing of small aneurysms with soft coils: an in vitro study. Neuroradiology. 2004;46(11):935-9.

30. Canton G, Levy DI, Lasheras JC. Changes in the intraaneurysmal pressure due to HydroCoil embolization. AJNR Am J Neuroradiol. 2005;26(4):904-7.

31. Ding YH, Dai D, Lewis DA, Cloft HJ, Kallmes DF. Angiographic and histologic analysis of experimental aneurysms embolized with platinum coils, Matrix, and HydroCoil. AJNR Am J Neuroradiol. 2005;26(7):1757-63.

32. Yoshino Y, Niimi Y, Song JK, Silane M, Berenstein A. Endovascular treatment of intracranial aneurysms: comparative evaluation in a terminal bifurcation aneurysm model in dogs. $\mathrm{J}$ Neurosurg. 2004;101(6):996-1003.

33. Kallmes DF, Cloft HJ. The use of hydrocoil for parent artery occlusion. AJNR Am J Neuroradiol. 2004;25(8):1409-10.

34. Brisman JL, Song JK, Niimi Y, Berenstein A. Treatment options for wide-necked intracranial aneurysms using a self-expandable hydrophilic coil and a self-expandable stent combination. AJNR Am J Neuroradiol 2005;26(5):1237-40.

35. Deshaies EM, Bagla S, Agner C, Boulos AS. Determination of filling volumes in HydroCoil-treated aneurysms by using threedimensional computerized tomography angiography. Neurosurg Focus. 2005;18(2):E5.

36. Arthur AS, Wilson SA, Barr JD. Hydrocoils for the treatment of cerebral aneurysms: experience with 110 cases (abstract). Neurosurgery. 2006;58(2):408.
37. Berenstein A, Song JK, Niimi Y, Namba K, Heran NS, Brisman JL, et al. Treatment of cerebral aneurysms with hydrogel-coated platinum coils: early results of the first 100 consecutive patients (abstract). Neurosurgery. 2006;58(2):409.

38. Park HK, Horowitz M, Jungreis C, Genevro J, Koebbe C, Levy E, et al. Periprocedural morbidity and mortality associated with endovascular treatment of intracranial aneurysms. AJNR Am J Neuroradiol. 2005;26(3):506-14.

39. Raftopoulos C, Mathurin P, Boscherini D, Billa RF, Van Boven M, Hantson P. Prospective analysis of aneurysm treatment in a series of 103 consecutive patients when endovascular embolization is considered the first option. J Neurosurg. 2000;93(2):175-82.

40. Bavinzski G, Killer M, Gruber A, Reinprecht A, Gross CE, Richling B. Treatment of basilar artery bifurcation aneurysms by using Guglielmi detachable coils: a 6-year experience. J Neurosurg. 1999;90(5):843-52.

41. Klein GE, Szolar DH, Leber KA, Karaic R, Hausegger KA. Basilar tip aneurysm: endovascular treatment with Guglielmi detachable coils--midterm results. Radiology. 1997;205(1):191-6.

42. Workman MJ, Cloft HJ, Tong FC, Dion JE, Jensen ME, Marx WF, et al. Thrombus formation at the neck of cerebral aneurysms during treatment with Guglielmi detachable coils. AJNR Am J Neuroradiol. 2002;23(9):1568-76.

43. Meyers PM, Lavine SD, Fitzsimmons BF, Commichau C, Parra A, Mayer SA, et al. Chemical meningitis after cerebral aneurysm treatment using two second-generation aneurysm coils: report of two cases. Neurosurgery. 2004;55(5):1222.

44. Willinsky RA, Taylor SM, TerBrugge K, Farb RI, Tomlinson G, Montanera W. Neurologic complications of cerebral angiography: prospective analysis of 2,899 procedures and review of the literature. Radiology. 2003;227(2):522-8. 